\title{
RANCANG BANGUN PENGENDALI KIPAS ANGIN BERBASIS MIKROKONTROLLER ATMEGA 16 MELALUI APLIKASI ANDROID DENGAN BLUETOOTH
}

\author{
Indah Purnamasari \\ Program Studi Sistem Informasi \\ Sekolah Tinggi Manajemen Informatika dan Komputer Nusa Mandiri Jakarta \\ Email: indah.ihi@nusamandiri.ac.id \\ Muhammad Rezasatria \\ Program Studi Teknik Komputer \\ Akademik Manajemen Informatika dan Komputer Bina Sarana Informatika \\ Email: muzasatria703@gmail.com
}

\begin{abstract}
ABSTRAK
Perkembangan teknologi membantu kita dalam pekerjaan. Khususnya teknologi yang berhubungan dengan pengendali otomatis yang terpasang pada berbagai peralatan elektronika dan digunakan seharihari. Peralatan elektronika yaitu kipas angin, saat ini difungsikan dengan cara manual yaitu menekan / memutar saklar atau dapat juga dilakukan dengan menggunakan alat khusus untuk kendali jarak jauh (remote). Sedangkan smartphone merupakan salah satu kemajuan teknologi masa kini yang dengan fiturfiturnya semakin mempermudah komunikasi maupun berbagai pekerjaan lain. Oleh karena itu pada umumnya untuk saat ini rata-rata semua orang memiliki ketergantungan terhadap smartphone sehingga hampir tidak terlepas dari smartphone. Penulisan ini melakukan rancang bangun suatu sistem untuk mengendalikan kecepatan kipas angin berbasis mikrokontroler ATmega16 yang dapat dikendalikan dari jarak jauh tanpa menggunakan alat khusus (remote) melainkan dengan menggunakan smartphone yang dimiliki sehingga akan lebih fleksibel bagi penggunanya. Dengan memanfaatkan teknologi yang ada pada smartphone berbasis android, penulisan ini mengembangkan sebuah aplikasi untuk mengendalikan kecepatan kipas angin menggunakan perantara bluetooth yang terdapat pada smartphone berbasis android. Dari hasil pengujian dapat dikatakan bahwa sistem ini memiliki kelebihan seperti penerapan yang sederhana dan sangat fleksibel untuk digunakan. Pada pengujian sistem pengendali ini, jarak jangkauan bluetooth antara kipas angin dan smartphone didapatkan jarak jangkauan maksimal 9 meter dalam keadaan terhalang tembok.
\end{abstract}

Kata kunci: ATmega16; bluetooth; android.

\begin{abstract}
Technological development helps us at work. Especially technology related to automatic controllers that are installed on various electronic equipment and used in everyday life. Electronic equipment, which is a fan, is now functioned manually by pressing / turning the switch or can also be done using a special tool for remote control. Whereas smartphones are one of today's technological advancements, with features that make communication easier and a variety of other jobs easier. Therefore, in general, for now, on average, everyone has a dependence on smartphones, so it is almost inseparable from smartphones. This writing designs a system to control the speed of an ATmegal6 microcontroller-based fan that can be controlled remotely without using a special device (remote) but by using a smartphone that is owned so that it will be more flexible for its users. By utilizing existing technology on Androidbased smartphones, this paper develops an application to control the speed of the fan using an intermediary bluetooth which is available on an Android-based smartphone. From the test results it can be said that this system has advantages such as simple application and very flexible to use. In testing this controller system, the range of bluetooth between the fan and smartphone has a maximum range of 9 meters in a blocked wall.
\end{abstract}

Keywords: ATmega16; bluetooth; android.

\section{PENDAHULUAN}

Indonesia sebagai salah satu negara tropis memiliki suhu udara yang cukup tinggi dan untuk mengatasinya maka berkembang berbagai peralatan teknologi elektronik berupa perangkat penyejuk 
ruangan seperti kipas angin, air cooler maupun air conditioner yang ukuran, fungsi dan teknologinya semakin bervariasi.

Perkembangan teknologi elektronika khususnya teknologi yang berhubungan dengan pengendali otomatis semakin berkembang sejalan dengan perkembangan ilmu dalam bidang otomatisasi. Teknologi pengendali otomatis ini diterapkan pada berbagai peralatan elektronik yang digunakan sehari-hari guna semakin membantu pekerjaan manusia.

Sistem pengendali otomatis merupakan sistem kontroler yang telah diprogram secara otomatis sesuai fungsinya, sehingga bisa memerankan seperti yang dilakukan manusia. Faktor manusia tidak dominan lagi dalam pengendalian karena telah dilakukan oleh sistem tersebut. Sistem pengendali otomatis ini bertujuan untuk semakin meringankan beban pekerjaan manusia dan keselamatan jiwa manusia terutama pada industri berat.

Selain dari itu, kemajuan teknologi telekomunikasi dan komputer menjadikan dunia teknologi semakin canggih terutama dengan munculnya sistem operasi Android yang banyak digunakan di berbagai smartphone dan komputer.

Smartphone adalah salah satu alat komunikasi yang praktis dan fleksible pemakaiannya bagi penggunanya. Perkembangan smartphone / tablet PC berbasis Android semakin meningkat tajam sehingga aplikasi - aplikasi mobile berbasis Android semakin meningkat. Android merupakan platform piranti bergerak yang open source software dan didukung oleh Google OS, pada mulanya dikembangkan oleh Google Inc. dan kemudian diselesaikan oleh Handset Alliance. Android menyediakan platform terbuka bagi para pengembang untuk menciptakan aplikasi mereka sendiri untuk digunakan oleh bermacam piranti bergerak [1].

Penelitian sebelumnya telah dilakukan oleh Joni Parhan dan Rahmat Rasyid yang berjudul Rancang Bangun Sistem Kontrol Kipas Angin dan Lampu Otomatis di Dalam Ruang Berbasis Arduino Uno R3 Menggunakan Multisensor [2]. Penelitian ini dilakukan dengan membuat system yang terdiri dari sensor PIR untuk mendeteksi manusia, sensor DHT11 yang berfungsi sebagai pendeteksi suhu dan kelembaban relatif, dan sensor LDR untuk mendeteksi intensitas cahaya di dalam ruangan. Mikrokontroler Arduino Uno R3 berfungsi sebagai pengolah data masukan dari sensor, mengatur relay bekerja, dan LDC menampilkan data data sensor. Sistem kontrol kipas angin dan lampu otomatis menunjukan sensor PIR HCSR501 dapat mendeteksi objek manusia pada jarak maksimum $6 \mathrm{~m}$ tepat di depan sensor.

Penelitian sebelumnya juga telah dilakukan oleh Dias Prihatmoko yang berjudul Perancangan dan Implementasi Pengontrol Suhu Ruangan berbasis mikrokontroler Arduino Uno [3] Penelitian ini dilakukan dengan membuat sistem kontrol suhu ini dilengkapi dengan kemampuan untuk mengontrol suhu ruangan yang dapat ditampilkan di LCD. Begitu pula pada penelitian [4] yang mengemukakan bahwa dengan alat bantu tertentu dapat bekerja secara otomatis untuk mengatur kecepatan kipas angin tersebut secara otomatis.

Metode perancangan sistem dimulai dari kajian arsitektur sistem, perencanaan sistem kontrol suhu, dan pembuatan prototype sistem kontrol suhu. Penelitian ini menghasilkan prototype suatu sistem pengontrol suhu pada kipas angin yang dilengkapi dengan fitur penampil suhu dengan LCD, sehingga suhu ruangan yang diharapkan akan tampil di LCD, apabila suhu tertampil diluar batas maksimum maka akan menghidupkan pendingin ruangan dan pendingin akan mati secara otomatis jika suhu berada dibawah batas minimum.

Pada penulisan ini merancang dan membangun suatu sistem pengendali otomatis berbasis mikrokontroler ATmega16 untuk kipas angin melalui aplikasi smartphone android menggunakan perantara bluetooth sehingga diharapkan dapat memberikan kemudahan pada pengguna untuk dapat memanfaatkan kipas angin secara maksimal dan lebih praktis.

Berbagai aplikasi dengan menggunakan mikrokontroler diantaranya untuk pengendalian peralatan listrik [5], Pengendali Pintu Air Daerah Aliran Sungai (Das) [6] pengendali elevator atau lift [7].

\section{METODOLOGI PENELITIAN}

Metode Penelitian yang digunakan dalam penelitian ini ditunjukkan pada gambar 1. 


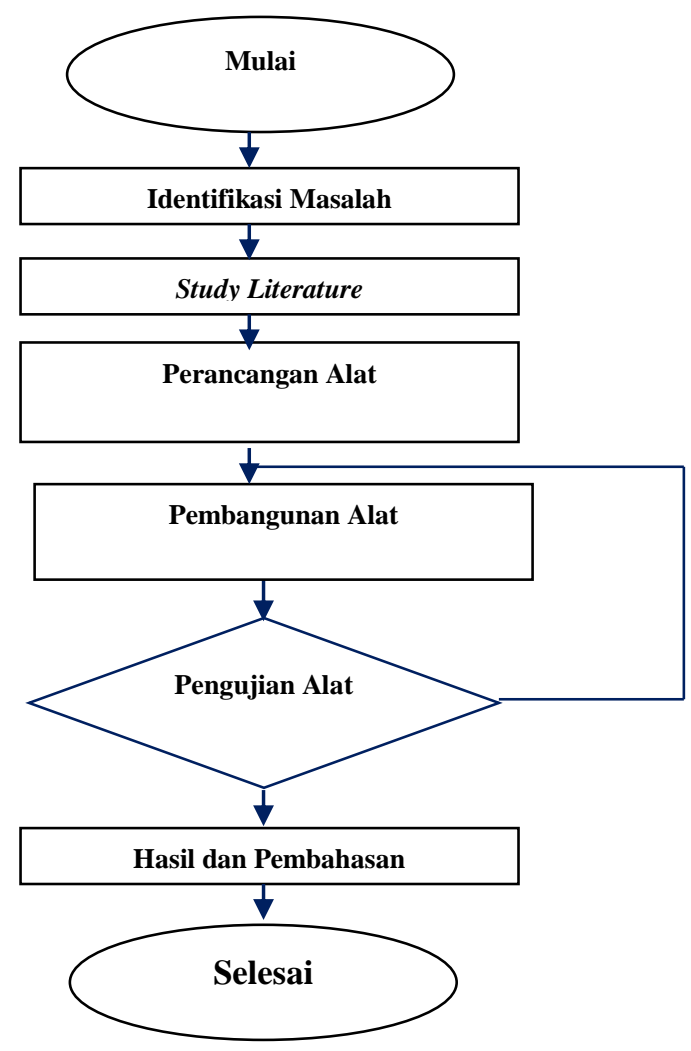

Gambar 1. Metodologi Penelitian

Gambar 1 menunjukkan metodologi penelitian yang digunakan dalam penulisan ini dimana metodologi penelitian adalah suatu metode yang melalui fase-fase dari identifikasi masalah, study literature, perancangan alat, pembangunan alat, pengujian alat dan di akhiri dengan analisa hasil.

Identifikasi masalah adalah pengenalan terhadap suatu masalah. Identifikasi masalah merupakan hal penting pada suatu penelitian yang dapat ditemukan melalui study literature dan observasi. Dalam penulisan rancang bangun ini, identifikasi masalah ditemukan melalui pengamatan langsung (observasi) yang terjadi di lapangan dan diperkuat dengan study literature.

Study literature dilakukan untuk mendapatkan referensi-referensi yang sesuai dengan identifikasi masalah penelitian dari berbagai sumber tertulis berupa jurnal, buku, artikel dan dokumentasi maupun dari internet. Perancangan merupakan suatu kegiatan mendesain suatu sistem baik alat termasuk program aplikasinya berdasarkan study literature yang telah dilakukan sebelumnya berkaitan dengan fungsi kerja alat yang akan di bangun dalam rancang bangun ini..

Pembangunan alat dilakukan dengan mengumpulkan bahan-bahan dan komponen - komponen yang telah di susun dalam perancangan. Sedangkan pembangunan aplikasi merupakan tahap untuk membuat sistem aplikasi pada android sehingga alat dapat bekerja sesuai yang diinginkan. Pengujian alat dan aplikasi merupakan kegiatan untuk melakukan pengetesan terhadap kerja alat dan aplikasi tersebut. Pengujian dilakukan biasanya berulang kali sampai mendapatkan hasil yang sesuai dengan tujuan rancang bangun ini. Hasil dan Pembahasan menunjukkan nilai - nilai hasil kerja dari alat dan aplikasi yang telah dibangun dan dilakukan pengujian.

\subsection{Identifikasi Masalah}

Identifikasi Masalah pada penelitian ini meliputi analisa terhadap permasalahan yang ada serta tujuan dari solusi terhadap masalah yang ada. Penulisan ini mengidentifikasi suatu permasalahan dimana alat penyejuk ruangan dalam hal ini kipas angin masih memiliki kelemahan yaitu pengguna tidak dapat menentukan suhu ruangan yang diinginkan dengan cara yang praktis. Atas dasar itu dalam penulisan ini akan membuat suatu sistem pengendali kipas angin berbasis mikrokontroller atmega16 menggunakan aplikasi smartphone android dengan tujuan dapat memberikan kemudahan pada penggunanya untuk memanfaatkan kipas angin secara maksimal dan lebih praktis. 


\subsection{Study Literature}

\subsubsection{Mikrokontroler}

Mikrokontroler adalah sebuah komputer mikro memiliki tiga komponen utama, yaitu: unit pengolahan pusat (CPU: Central Processing Unit), memori dan system I/O (Input/output) untuk dihubungkan ke perangkat luar [8]. Dalam sebuah IC atau chip mikrokontroler terdapat CPU, memori, saluran komunikasi serial dan paralel, port input atau output, ADC, dll. Mikrokontroler digunakan sebagai pengendali yang mengatur semua proses. Mikrokontroler merupakan suatu komponen elektronika yang didalamnya terdapat rangkaian mikroprosesoor, memori (RAM atau ROM) dan I/O, rangkaian tersebut terdapat dalam level chip. Pada mikrokontroler sudah terdapat komponen-komponen mikroprosesor, dengan bus-bus internal yang saling berhubungan, komponen-komponen tersebut adalah RAM, ROM, Timer, I/O paralel dan serial, serta Interupt Control. Dalam hal ini penulis menggunakan mikrokontroler ATmega16 yang ditunjukkan pada gambar 2 dibawah ini. Gambar 3 menunjukkan keterangan untuk masing masing kaki mikrokontroler ATmega16.

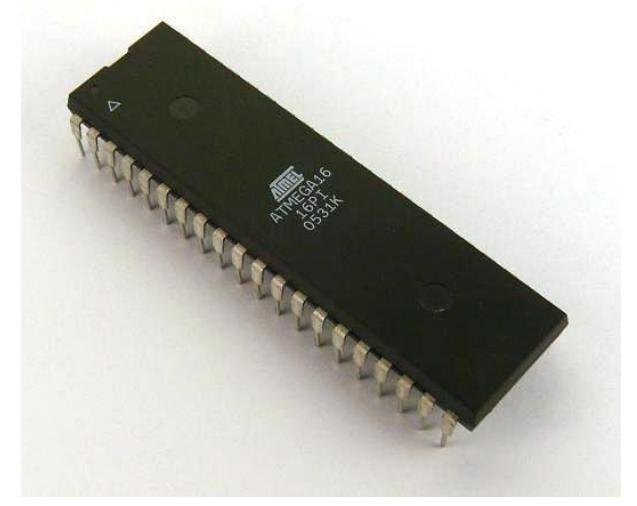

Gambar 2. Mikrokontroler ATmega16

Sumber: http://www.engineersgarage.com/

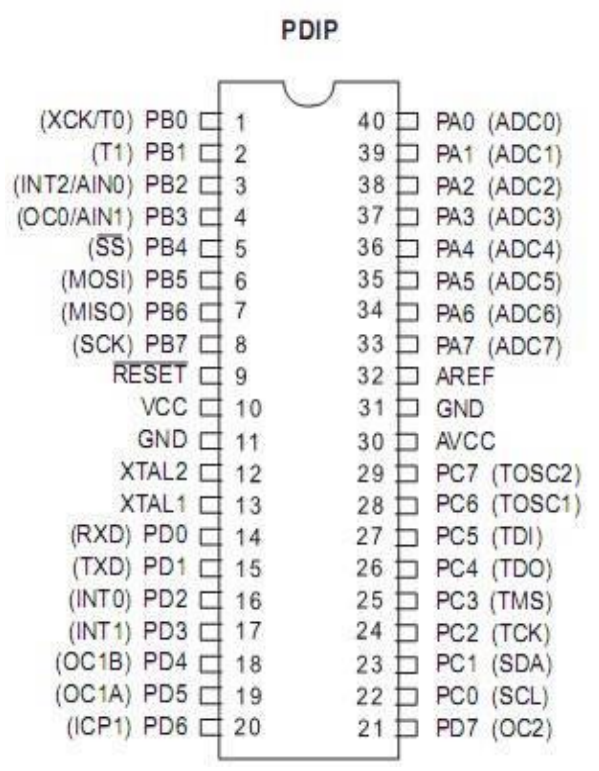

Gambar 3. Pin ATMega 16

Sumber: https://www.futurlec.com/ 


\subsubsection{Bluetooth $\mathrm{HC}-05$}

Bluetooth adalah teknologi komunikasi tanpa kabel yang menyediakan layanan komunikasi secara real-time antar perangkat Bluetooth dengan jarak layanan yang lebih jauh dari media infra merah [9]. Teknologi bluetooth yang memungkinkan dua perangkat yang kompatibel, seperti telepon dan PC untuk berkomunikasi tanpa kabel dan memerlukan koneksi saluran yang terlihat. Teknologi bluetooth memberikan perubahan signifikan terhadap perlatan elektronik yang kita gunakan. bluetooth berbeda dengan wifi (keluarga 802.11), standart yang digunakan oleh bluetooth mengacuh pada spesifikasi IEEE 802.15. bluetooth menggunakan frekuensi $2,4 \mathrm{GHz}$ dengan kecepatan transfer data kurang dari $1 \mathrm{Mbps}$ (sekitar $800 \mathrm{Kbps)}$. Sebuah peralatan bluetooth dapat berkomunikasi dengan peralatan lain yang berbeda pada jarak 13 Meter. Saat ini telah dikembangkan standart baru yang dapat menjangkau jarak sekitar 100 Meter (tanpa pengahalang). Modul bluetooth HC-05 ditunjukkan pada gambar 4.

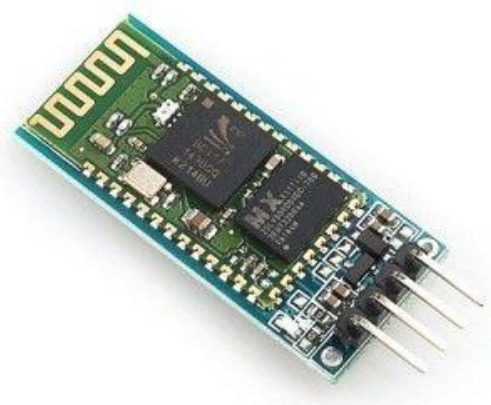

Gambar 4. Bluetooth HC-05

Sumber : http://csharpcorner.mindcrackerinc.com/

\subsubsection{Kipas Angin DC}

Kipas angin menggunakan motor listrik untuk mengubah energi listrik menjadi gerakan balingbaling[10]. Dalam Kipas Angin DC terdapat suatu kumparan besi pada bagian yang bergerak beserta sepasang pipih yang berbentuk magnet pada bagian yang diam. Ketika listrik mengalir pada lilitan kawat dalam kumparaan besi, hal ini membuat kumparan besi menjadi sebuah magnet. Karena sifat magnet yang saling tolak-menolak pada kedua kutubnya maka gaya tolak-menolak magnet antara kumparan besi dan sepasang magnet tersebut membuat gaya berputar secara periodik pada kumparan besi tersebut. Oleh karena itu baling-baling kipas angin dikaitkan ke poros kumparan tersebut. Penambahan tegangan listrik pada kumparan besi dan menjadi gaya kemagnetan ditujukan untuk memperbesar hembusan angin pada kipas angin. Kipas Angin DC pada gambar 5 ini memakai tegangan sebesar 5 volt.

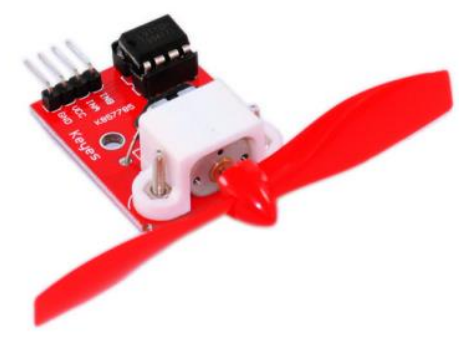

Gambar 5. Kipas Angin DC

Sumber : https://ae01.alicdn.com/ 


\subsection{Perancangan Alat}

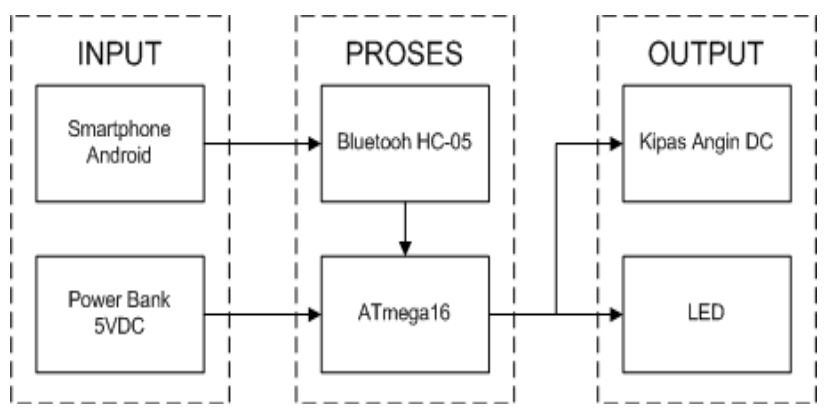

Gambar 6. Blok Diagram

Penjelasan gambar 6 blok diagram alat penyejuk ruangan menggunakan aplikasi android melalui Bluetooth HC-05 adalah sebagai berikut :

a) Input

Komponen input ini merupakan komponen masukan yang akan di proses. Komponen input terdiri dari:

1) Powerbank 5VDC 1A merupakan masukan tegangan searah 5 Volt yang dialirkan kedalam rangkaian sistem minimum ATmega16, Kipas angin DC, LED serta Bluetooh HC-05.

2) Smartphone Android berfungsi untuk mengendalikan Modul kipas dan LED.

b) Proses

Proses merupakan komponen utama yang berfungsi sebagai pengelola data yang diterima dari masukan yang kemudian akan menghasilkan output. Dalam proses ini penulis menggunakan :

1) Mikrokontroler ATmega16 yang berfungsi sebagai pusat pemrosesan rangkaian elektronik.

2) Bluetooth $\mathrm{HC}-05$ digunakan untuk menerima data dari smartphone android ke mikrokontroler Atmega16.

c) Output

Output merupakan keluaran dari semua proses yang telah dijalankan. Output yang dihasilkan yaitu :

1) Kipas angin DC.

2) LED berfungsi sebagai lampu indikator

\subsection{Pembangunan Alat}

\subsubsection{Skema Rangkaian Alat}

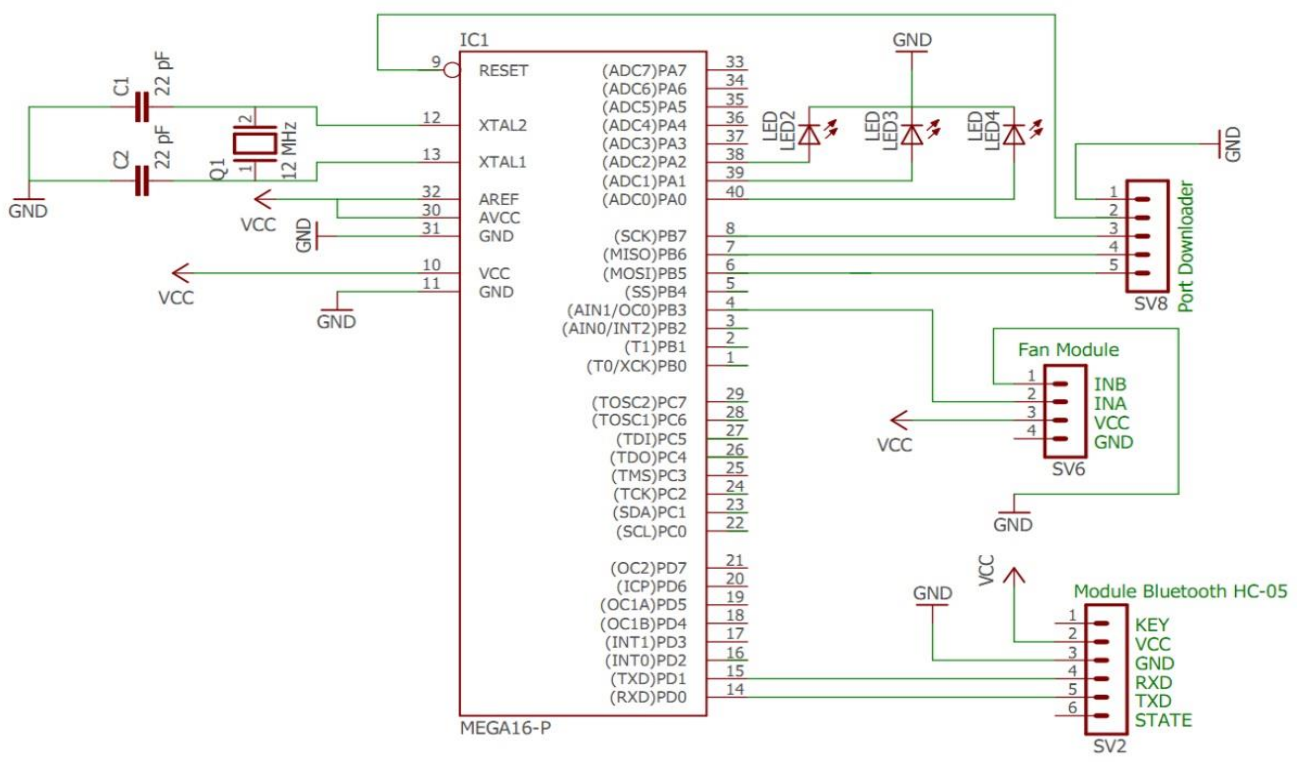

Gambar 7. Skema Rangkaian Alat

Gambar 7 menunjukkan skem rangkaian alat. Pada rangkaian ini mikrokontroller Atmega16 sebagai pusat pemerosesan data, Bluetooth HC-05 sebagai pemerintah sensor, dan komponen rangkaian 
elektronika lainnya sebagai pendukung. Agar sistem bekerja dan aktif, hubungkan sistem dengan power bank, jika Kipas angin DC pada sistem bergerak tandanya bahwa alat siap diperintah, jika Kipas angin DC tidak bergerak maka periksa tegangan pada power bank.

Untuk memerintahkan sistem, aktifkan sistem pada aplikasi yang dihubungkan dengan Bluetooth smartphone. Maka Bluetooth $\mathrm{HC}$-05 pada alat akan menerima perintah yang dijalankan diaplikasi smartphone. Perangkat hardware yang digunakan dalam pembuatan alat ini dapat dilihat dalam tabel 1 berikut ini:

Tabel 1. Komponen yang diperlukan

\begin{tabular}{|c|c|c|}
\hline No & Nama Komponen & Jumlah \\
\hline 1. & ATmega16 + Socket & 1 \\
\hline 2. & Kapasitor $22 \mathrm{pF}$ & 2 \\
\hline 3. & Crystal $12 \mathrm{MHz}$ & 1 \\
\hline 4. & Resistor $220 \Omega$ & 5 \\
\hline 5. & Kapasitor $1000 \mathrm{uF} / 16 \mathrm{~V}$ & 1 \\
\hline 6. & Kapasitor $330 \mathrm{nF}$ & 1 \\
\hline 7. & Kapasitor $100 \mathrm{nF}$ & 1 \\
\hline 8. & Kipas Angin DC & 1 \\
\hline 9. & Bluetooth HC-05 & 1 \\
\hline 10. & LED Hijau 5MM & 1 \\
\hline 11. & LED Merah 5MM & 1 \\
\hline 12. & LED Kuning 5MM & 1 \\
\hline 13. & LED Biru 5MM & 1 \\
\hline 14. & Pin header & 1 \\
\hline 15. & Kabel jumper & 1 Meter \\
\hline 16. & PCB fiber & 1 \\
\hline 17. & Baut spicer $2 \mathrm{CM}$ & 8 \\
\hline 18. & Kabel USB & $30 \mathrm{CM}$ \\
\hline
\end{tabular}

Penjelasan dari skema rangkaian alat ini adalah sebagai berikut:

a) Rangkaian Kipas angin DC menggunakan mikrokontroler ATmega16 sebagai pusat pemroses data dan Bluetooth HC-05 sebagai penghubung antara Smartphone Android dengan mikrokontroler ATmega16.

b) Untuk menjalankan alat penyejuk ruangan menggunakan aplikasi Android, hubungkan rangkaian dengan catu daya 5 VDC. Jika LED indikator pada rangkaian sistem minimum menyala, maka alat tersebut siap digunakan, jika LED indikator tidak menyala, maka periksa kembali sumber tegangan pada rangkaian sistem minimum.

Sedangkan untuk membangun aplikasi android yaitu menggunakan situs MIT Appinventor dengan bahasa pemrograman yang kompleks berbasis teks menjadi berbasis visual (drag and drop) berbentuk blok-blok. 


\subsubsection{Flowchart}

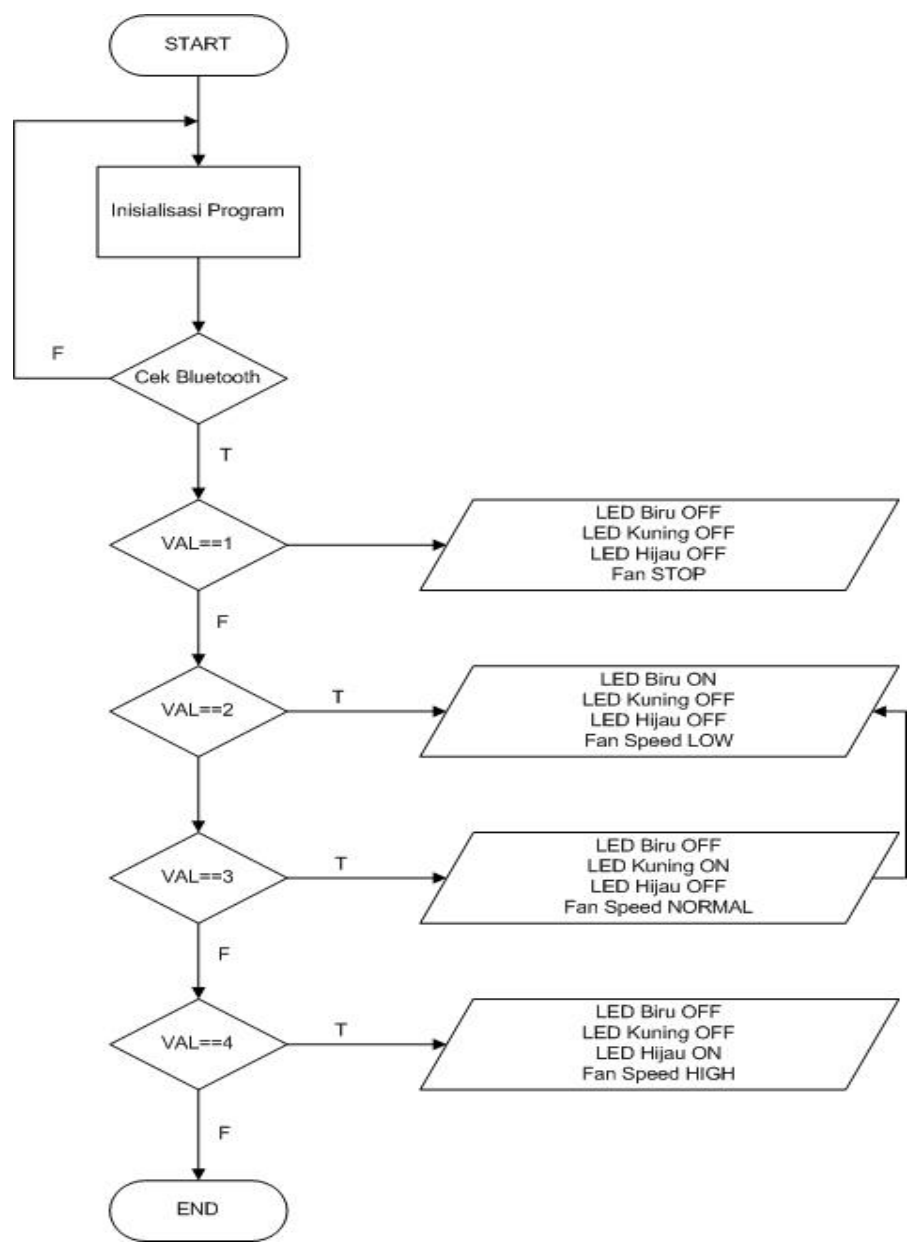

Gambar 8. Flowchart

\subsubsection{Listing Program}

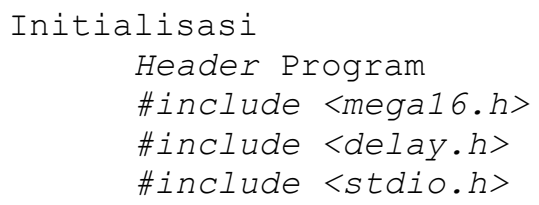

Atmega16.h berfungsi untuk memanggil library dari ATmega16. delay.h untuk memanggil fungsi delay_ms. Dan stdio.h berfungsi untuk memanggil fungsi getchar()\#define pwm OCRO berfungsi untuk meringkas serta mengubah defini dari $O C R O$ agar bisa di panggil dengan perintah PWM. char val;membuat variabel val dengan tipe data char.

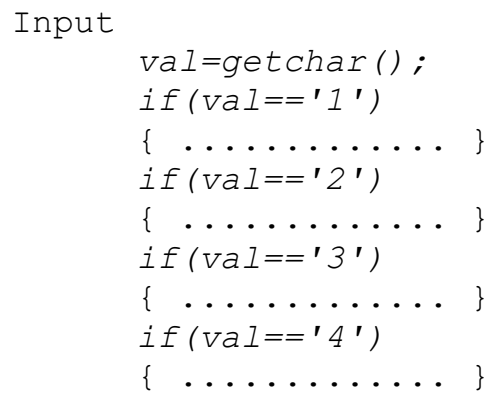


Apabila Smartphone Android mengirimkan perintah karakter '1' maka perintah karakter tersebut akan di terima oleh Bluetooth HC-05 yang selanjutnya di terima atau getchar() oleh mikrokontroler, maka karakter yang berupa ' 1 ' akan mengisi variabel val. Selanjutnya variabel tersebut akan masuk dalam kondisi percabangan atau decision. Mulai dari 1,2,3 dan 4.

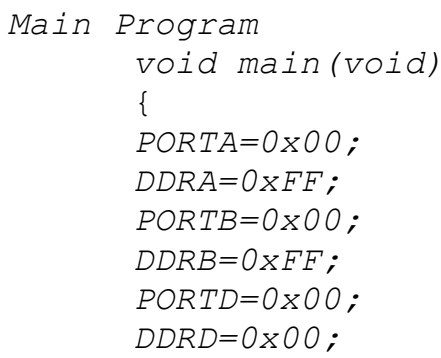

$D D R A, D D R B$ di beri nilai $O x F F$ artinya port tersebut di atur sebagai keluaran atau output. PORTA, $P O R T B$ diberi nilai $0 x 00$ artinya ketika alat penyejuk ruangan ini di nyalakan maka kondisi port tersebut dalam kondisi $O F F$. Sedangkan $D D R D$ di beri nilai $0 x 00$ artinya port tersebut di atur sebagai masukan atau input. PORTD diberi nilai $0 x 00$ artinya ketika alat di nyalakan maka kondisi masukan atau input dalam kondisi default atau belum ada masukan.

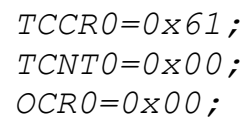

TCCRO diberi nilai Ox61 karena pada sistem minimum menggunakan Crystal $12 \mathrm{MHz}$. TCNTO di beri nilai $0 x 00$ sebagai inisialisasi Timer 0 dan OCR0 diberi nilai 0x00 agar kondisi $P W M$ ketika di nyalakan dalam kondisi $O F F$.

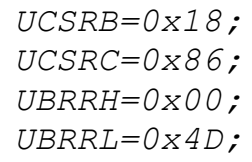

Komunikasi menggunakan parameter : 8 data, 1 stop dan parity. Atur UART Receiver dan Transmitter dalam posisi On. Mode UART menggunakan Asynchronous. Dalam alat penyejuk ruangan ini menggunakan komunikasi serial dengan baud rate 9600

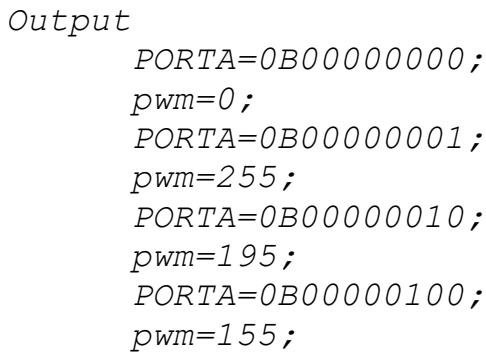

PORTA diberi nilai OB00000001 dalam kondisi biner atau 0x00 dalam kondisi heksadesimal. Artinya PORTA pada port pertama akan mengeluarkan tegangan atau dalam kondisi High. Dan PWM adalah kecepatan dari putaran Kipas angin DC. Memiliki kecepatan maksimal dan minimal. Untuk kecepatan maksimal sebesar 255 dan kecepatan minimal sebesar 0. PWM tersebut berada dalam PORTB pada port urutan ke empat

\subsection{Pengujian Alat}

Setelah melakukan perencanaan dan perancangan, selanjutnya perlu dilakukan percobaan dan pengukuran untuk pengujian alat. Dalam Percobaan dan analisa sistem, terlebih dahulu harus menjalankan rangkaian secara benar dalam pemasangan dan integrasi hardware maupun software.

Percobaan berguna untuk menghindari kesalahan-kesalahan yang terjadi, langkah ini untuk mengetahui kondisi peralatan yang direncanakan sudah dapat berjalan dengan baik dan sesuai dengan 
yang dikehendaki atau tidak. Percobaan yang dilakukan pada bab ini antara lain, Percobaan mengirim dan menerima data menggunakan mikrokontroler dan diteruskan menggunakan transmitter dari Smartphone Android, percobaan untuk menyalakan dan mematikan LED, percobaan untuk menggerakan Kipas angin DC, percobaan jarak jangkauan bluetooth dan percobaan keseluruhan alat. Apakah hasilnya sesuai dengan data sebenarnya dan Percobaan alat secara keseluruhan.

\section{HASIL DAN PEMBAHASAN}

Hasil percobaan diperoleh setelah melakukan pengujian dilakukan untuk mengetahui apakah sistem sudah berjalan sesuai dengan perencanaan yang telah dibuat. Percobaan dilakukan pada beberapa bagian secara terpisah, kemudian dilakukan dalam sistem yang telah terintegrasi.

\subsection{Hasil Pengujian Pengiriman Karakter}

Tabel 2 menunjukkan hasil pengujian pengiriman karakter 1, 2,3, dan 4 sebagai karakter yang digunakan untuk mengatur kecepatan kipas angin.

Tabel 2. Pengujian pengiriman karakter

\begin{tabular}{|c|c|c|c|}
\hline No & Percobaan & Test Case & Hasil Percobaan \\
\hline 1 & $\begin{array}{l}\text { Mengirimkan } \\
\text { Karakter ' } 1 \text { ' }\end{array}$ & Bluetooh.SendText='1' & Mikrokontroler membaca karakter ' 1 ' \\
\hline 2 & $\begin{array}{l}\text { Mengirimkan } \\
\text { Karakter '2' }\end{array}$ & Bluetooh.SendText='2' & Mikrokontroler membaca karakter ' 2 ' \\
\hline 3 & $\begin{array}{l}\text { Mengirimkan } \\
\text { Karakter ' } 3 \text { ' }\end{array}$ & Bluetooh.SendText='3' & Mikrokontroler membaca karakter ' 3 ' \\
\hline 4 & $\begin{array}{l}\text { Mengirimkan } \\
\text { Karakter '4' }\end{array}$ & Bluetooh.SendText= '4' & Mikrokontroler membaca karakter ' 4 ' \\
\hline
\end{tabular}

\subsection{Pengujian Jarak Bluetooh Terhalang oleh Ruangan/tembok}

Hasil pengujian jarak bluetooth dalam keadaan terhalang tembok dapat dilihat pada tabel 3 di bawah ini dimana jarak maksimal yang diperoleh yaitu 9 meter dengan waktu respon terhadap alat saat tombol ditekan yaitu $0,1-0,2$ detik

Tabel 3. Pengujian jarak bluetooh terhalang oleh ruangan / tembok

\begin{tabular}{ccc}
\hline Jarak (meter) & Kondisi (terhalang oleh ruangan/tembok) & $\begin{array}{c}\text { Waktu Respon terhadap } \\
\text { Alat saat Tombol ditekan }\end{array}$ \\
\hline 0 & Alat merespon input dari android & 0,1 detik \\
1 & Alat merespon input dari android & 0,1 detik \\
2 & Alat merespon input dari android & 0,1 detik \\
3 & Alat merespon input dari android & 0,1 detik \\
4 & Alat merespon input dari android & 0,1 detik \\
5 & Alat merespon input dari android & 0,1 detik \\
6 & Alat merespon input dari android & 0,1 detik \\
7 & Alat merespon input dari android & 0,2 detik \\
8 & Alat merespon input dari android & 0,2 detik \\
9 & Alat merespon input dari android & 0,2 detik \\
10 & Alat tidak merespon input dari android & Error connection \\
\hline
\end{tabular}

Untuk percobaan seluruh sistem dapat dilakukan percobaan pengiriman data dari Smartphone Android dan selanjutnya di terima oleh Bluetooth HC-05. Data yang telah diterima oleh Bluetooth HC-05 akan di proses oleh mikrokontroler Atmega16 dan akan menggerakan Kipas angin DC maupun menyalakan LED. Hasil pengujian keseluruhan sistem dapat dilihat pada tabel 4. 
Tabel 4. Hasil keseluruhan

\begin{tabular}{lll}
\hline No & Nama Percobaan & Hasil Percobaan \\
\hline 1 & Kipas Angin Off & Semua LED Mati dan Kipas tidak berputar \\
2 & Low Speed & Hanya LED Biru menyala dan kecepatan kipas pelan \\
3 & Normal Speed & Hanya LED Kuning menyala dan kecepatan kipas sedang \\
4 & High Speed & Hanya LED Hijau menyala dan kecepatan kipas kencang \\
\hline
\end{tabular}

Hasil tampilan aplikasi pada smartphone android yang digunakan untuk mengendalikan kipas angin menggunakan situs MIT Appinventor menggunakan bahasa pemrograman yang kompleks berbasis teks menjadi berbasis visual (drag and drop) berbentuk blok-blok ditunjukan pada gambar di bawah ini :

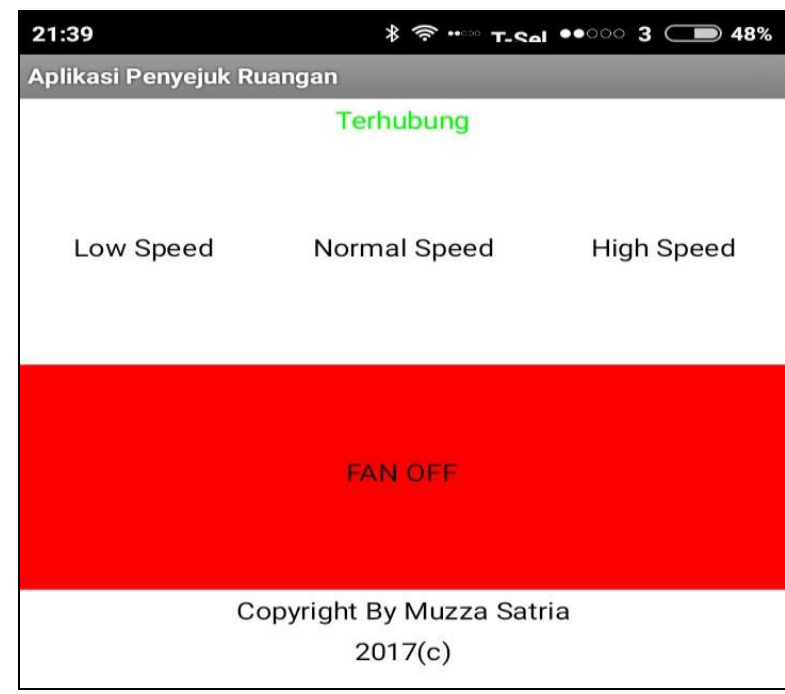

Gambar 9. Tampilan Fan Motor DC Stop

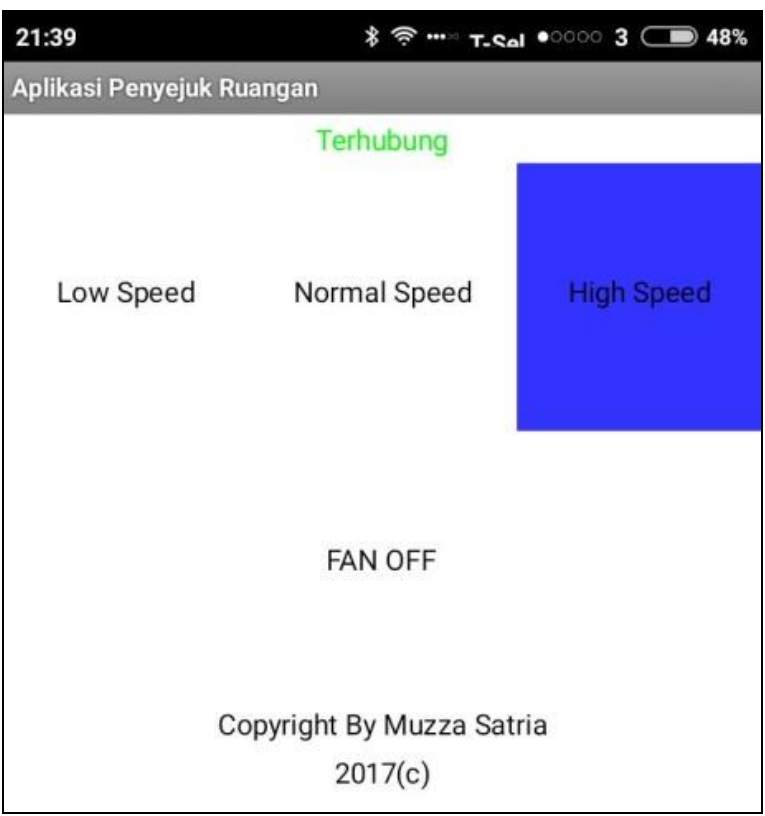

Gambar 10. Tampilan Fan Motor DC Fast 


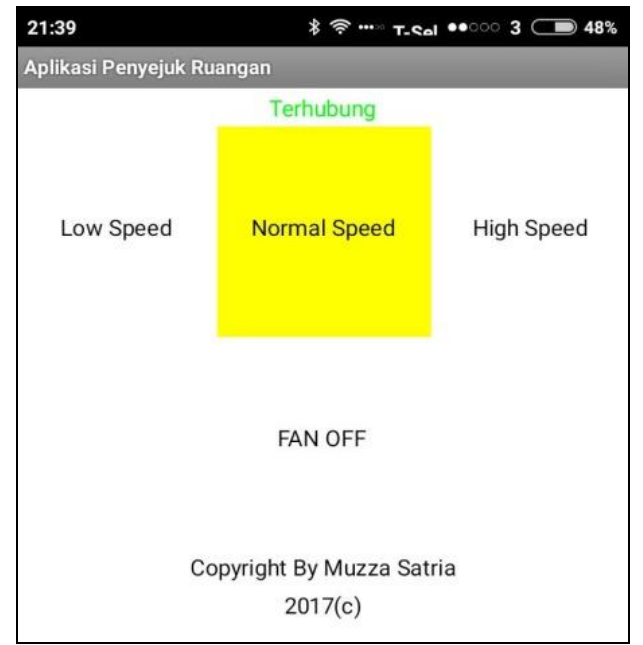

Gambar 11. Tampilan Fan Motor DC Normal

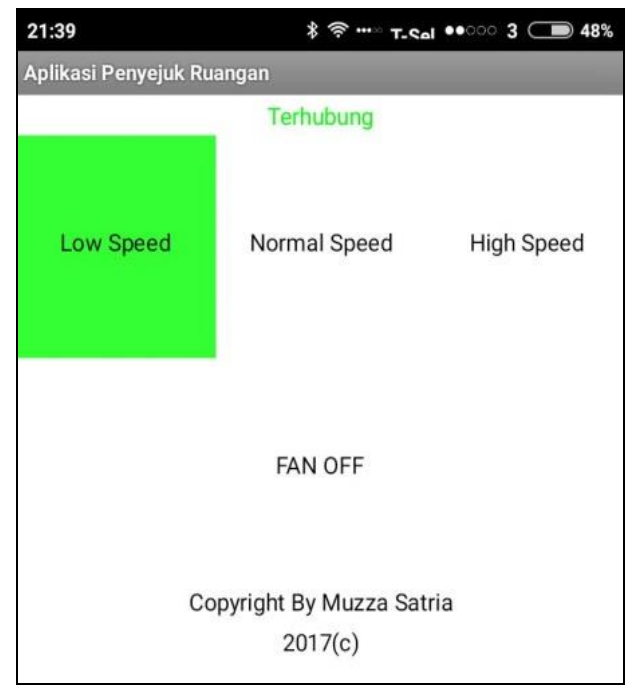

Gambar 12. Tampilan Fan Motor DC Low

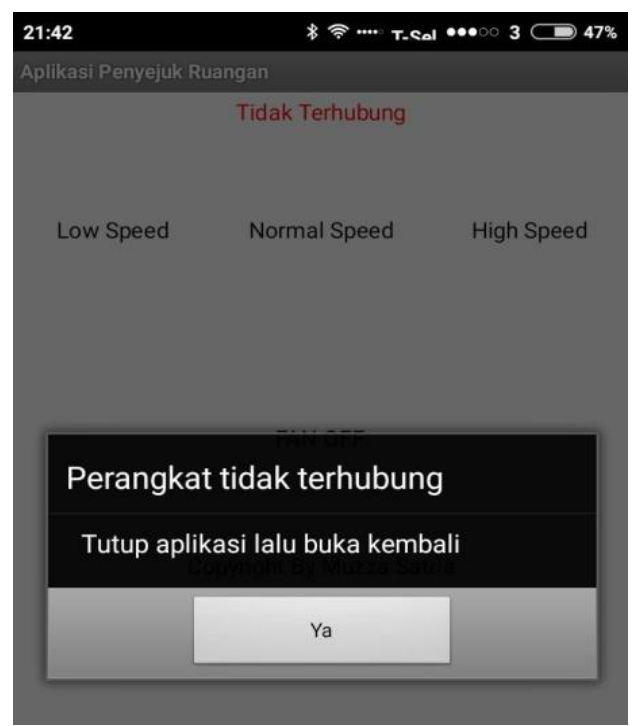

Gambar 13. Tampilan Peringatan Koneksi ke Alat Terputus 


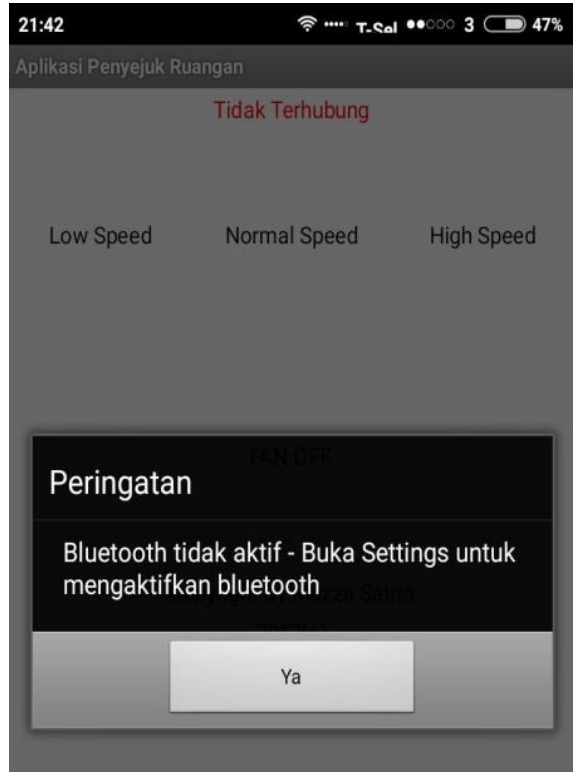

Gambar 14. Tampilan Peringatan untuk Mengaktifkan Bluetooth

\section{KESIMPULAN}

Berdasarkan hasil perancangan dan pengujian terhadap alat pengendali kipas angin menggunakan aplikasi Android melalui Bluetooth HC-05 berbasis mikrokontroler ATmega16, maka dapat disimpulkan bahwa:

a) Bluetooth $\mathrm{HC}$-05 bekerja secara efektif antara 0 sampai 9 meter.

b) Pengaturan kecepatan pwm minimal dan maksimal pada Kipas Angin DC hanya berkisar dan 0 sampai 255, apabila tidak sesuai dengan batas minimal dan maksimal, maka Kipas Angin DC tidak akan bergerak.

c) Membangun aplikasi android dengan menggunakan situs MIT Appinventor menggunakan bahasa pemrograman yang kompleks berbasis teks menjadi berbasis visual (drag and drop) berbentuk blokblok

d) Program yang terdapat pada Atmega16 dibangun dengan menggunakan perangkat lunak Code Vision AVR dengan menggunakan bahasa pemrograman $\mathrm{C}$

\section{DAFTAR PUSTAKA}

[1] Sulihati, A. (2016). Aplikasi Akademik Online Berbasis Mobile Android Pada Universitas Tama Jagakarsa, Volume XI, Nomor 1, Hal 18-19. Universitas Tama. Jagakarsa, XI(April), 15-26.

[2] Alisman, W. (2018). Rancang Bangun Sistem Kontrol Gorden , Lampu , dan Kipas Angin Berbasis Arduino Uno R3. Jurnal Fisika Unand, 7(3), 279-285.

[3] Prihatmoko, D. (2017). Perancangan Dan Implementasi Pengontrol Suhu Ruangan Berbasis Mikrokontroller Arduino Uno. Simetris : Jurnal Teknik Mesin, Elektro Dan Ilmu Komputer, 7(1), 117. http://doi.org/10.24176/simet.v7i1.495.

[4] Andista, A., Ramadhon, C., Suraatmadja, M. S., Rusdinar, A., Elektro, F. T., Telkom, U., \& Logic, F. (2016). Rancang Bangun Pengendali Motor Kipas Angin Dengan Mengunakan Metode Logika Fuzzy Dan Image Processing Design Control Motor Fan Using Method Fuzzy Logic and Image, 3(1), 28-34.

[5] SAPUTRI, Z. N. (2014). Aplikasi Pengenalan Suara Sebagai Pengendali Peralatan Listrik Berbasis Arduino Uno. Aplikasi Pengenalan Suara Sebagai Pengendali Peralatan Listrik Berbasis Arduino Uno, 1,8 .

[6] Kusumawardhani, A., Nurdin, S., \& Sari, M. S. A. (2017). Teknologi Smartphone Android Dan Aplikasinya Sebagai Pengendali Pintu Air Daerah Aliran Sungai (Das). Teknika: Engineering and Sains Journal, 1(2), 89-94. http://doi.org/10.5281/zenodo.1116477

[7] Adriansyah, A., \& Hidyatama, O. (2013). Elevator atau Lift. Teknik Elektro, 4(3), 120-132.

[8] Son, M. S. (2018). Pengembangan Mikrokontroler Sebagai Remote Control Berbasis Android. Jurnal Teknik Informatika, 11(1), 67-75. http://doi.org/10.15408/jti.v11i1.6293

[9] Rahmiati, P., Firdaus, G., \& Fathorrahman, N. (2017). Implementasi Sistem Bluetooth menggunakan Android dan Arduino untuk Kendali Peralatan Elektronik. Jurnal Elkomika, 2(1), 1- 
Jurnal SIMETRIS, Vol. 10 No. 1 April 2019

P-ISSN: 2252-4983, E-ISSN: 2549-3108

14. http://doi.org/10.26760/elkomika.v2i1.1.

[10] Prihanto, M. D. (2017). Pengendali kipas angin dari jarak jauh dengan arduino dan wifi. 